\title{
THE INTRACELLULAR MEDIATION DURING CHRONIC FLUORIDE INTOXICATION IN RATS
}

\author{
Irina BAGMUT ${ }^{1}$, Igor KOLISNYK ${ }^{1}$, Anna TITKOVA ${ }^{1}$, Svetlana GRAMATIUK ${ }^{1}$, Liudmyla \\ SVYRYDENKO ${ }^{1}$
}

${ }^{1}$ Department of Clinical Pathophysiology, Topographic Anatomy and Operative Surgery, Kharkiv Medical Academy of Postgraduate Education, Kharkiv, Ukraine

Received 18 Apr 2019, Accepted 29 June 2019

hitps://doi.org/10.31688/ABMU.2019.54.3.02

\section{Abstract}

The objective of the study was to evaluate the intracellular cyclase cascade under the conditions of chronic fluoride intoxication in white rats of the Wistar population.

Materials and methods. The study was conducted from 2009 to 2014 in the Department of Biochemistry and vivarium of Kharkiv National Medical University $\mathrm{MOH}$, Kharkiv, Ukraine. The study was performed on white rats of the Wistar population. In these rats, we administered intragastric, in the morning, on an empty stomach, a solution of sodium fluoride at a rate of $20 \mathrm{mg} / \mathrm{kg}$ of body weight. In this way, the development of fluoride intoxication was simulated. The duration of oral administration of the drug was 1.5 months. The intracellular metabolism was assessed in plasma, liver, kidneys, spleen, and brain cortex. The energy components of the adenylate cyclase system, adenosine monophosphate (AMP), adenosine diphosphate (ADP), adenosine triphosphate (ATP), inorganic phosphorus and ions of $\mathrm{Mg}^{2+}$, guanylate cyclase, phosphodiesterase, were measured. The organs and tissues content of cyclic adenosine monophosphate (cAMP), cyclic guanosine monophosphate (cGMP) and absorption of $\mathrm{Ca}^{2+}$ by the liver membranes microsomes and synaptosomes of the brain were also determined.

\section{Résumé}

La médiation intracellulaire au cours de l'intoxication chronique de fluorure chez les rats

L'objectif de l'étude était d'évaluer la cascade des cyclases intracellulaires dans les conditions d'intoxication chronique au fluorure chez les rats blancs de la population de Wistar.

Matériaux et méthodes. La recherche dans ce domaine a été menée par le groupe créatif de la recherche scientifique de 2009 à 2014 dans le Département de biochimie et dans le vivarium de l'Université nationale de médecine de Kharkiv, Kharkiv, Ukraine. Chez ces rats blancs de la population Wistar, on a administré une solution de fluorure de sodium à taux de $20 \mathrm{mg} /$ $\mathrm{kg}$ de poids, le matin à jeun, simulant le développement d'une intoxication au fluorure. La durée de l'administration orale du médicament était de 1,5 mois. Le métabolisme intracellulaire a été évalué dans le plasma, le foie, les reins, la rate et le cortex cérébral. Les composants énergétiques du système de l'adénylate cyclase, l'adénosine monophosphate (AMP), l'adénosine diphosphate (ADP), l'adénosine triphosphate (ATP), le phosphore inorganique et les ions de $\mathrm{Mg} 2+$, la guanylate cyclase et la phosphodiésterase ont été mesurés. Le contenu dans les organes et les tissus d'adénosine 
Results. The increase in the content of cAMP and a decrease in the level of cGMP were observed in the blood plasma of animals, whereas a decrease in the concentration of cAMP and an increase in the amount of cGMP were observed in the liver, kidneys and spleen. In the cerebral cortex, a decrease in adenylate cyclase activity and cAMP content has been established. At the same time, the activity of guanylate cyclase, phosphodiesterase, and cGMP content increased.

Conclusions. Analysis of the absorption of $\mathrm{Ca}^{2+}$ membranes by macrosomes of the liver and brain synaptosomes revealed a decrease in basal and $\mathrm{K}^{+}$- stimulated absorption of calcium ions by membrane preparations of nerve cells. In the liver, the $\mathrm{K}^{+}$-stimulated and basal absorption of $\mathrm{Ca}^{2+}$ ions was significantly less than in the brain.

Keywords: intracellular metabolism, liver macrosomes, brain synaptosomes, Wistar white rats.

\section{List of abbreviations:}

AMP = adenosine monophosphate

$\mathrm{ADP}=$ adenosine diphosphate

ATP $=$ adenosine triphosphate

cAMP = cyclic adenosine monophosphate

cGMP = cyclic guanosine monophosphate

$\mathrm{AC}=$ adenylate cyclase

\section{INTRODUCTION}

One of the recent discoveries of biochemistry and physiology is considered to be the biological role of adenosine 3', 5'- monophosphate, or, as it is commonly called, cyclic adenosine monophosphate (cAMP) and guanosine 3', 5'-monophosphate (cGMP) ${ }^{1,2}$. Initially, cAMP was established as an intracellular mediator of the action of various biogenic amines and polypeptide hormones. Subsequently, the concept of a "secondary" mediator was proposed, according to which biogenic amines, hormones ("first" mediators) change the concentration of cAMP within cells, which leads to a change in the metabolic rates of various processes in cell ${ }^{3 \cdot 7}$.

Cyclic adenine monophosphate is synthesized from ATP with the participation of the enzyme adenylate cyclase $(\mathrm{AC})^{8}$. In most cells, this enzyme is localized in the plasma membrane. In the nervous tissue, the $\mathrm{Mg}^{2+}$-containing enzyme is also found in mitochondria and microsomes and is a membrane-bound enzyme. The enzyme hydrolyzing cAMP to 5'-ATP is cyclonucleotide phosphodiesterase (3', 5'-cAMP-phosphodiesterase) ${ }^{9,10}$. This is the only enzymatic reaction leading to deactivation of cAMP. The highest cAMP-phosphodiesterase activity is found in the cerebral cortex ${ }^{11}$. monophosphate cyclique (AMPc), de guanosine monophosphate cyclique (GMPc) et de l'absorption de $\mathrm{Mg} 2+$ par le microsome des membranes hépatiques a été aussi déterminé.

Résultats. L'augmentation de la teneur en AMPc et une diminution du taux de GMPc ont été observées dans le plasma sanguin des animaux, alors qu'une diminution de la concentration en AMPc et une augmentation de la quantité de GMPc ont été observées dans le foie, les reins et la rate. Dans le cortex cérébral, une diminution de l'activité de l'adénylate cyclase et de la teneur en AMPc a été établie. Dans le même temps, l'activité de la guanylate cyclase, de la phosphodiestérase et du cGMP a augmenté.

Conclusions. L'analyse de l'absorption des membranes $\mathrm{Ca}^{2+}$ par les macrosomes du synaptosome du foie et du cerveau a révélé une diminution de l'absorption basale, stimulée par le $\mathrm{K}^{+}$des ions de calcium par les préparations membranaires de cellules nerveuses. Dans le foie, l'absorption basale des ions $\mathrm{Ca}^{2+}$ stimulée par le $\mathrm{K}^{+}$était significativement inférieure à celle du cerveau.

Mots-clés: métabolisme intracellulaire, macrosomes du foie, synaptosomes cérébraux, rats blancs Wistar.

It has now been established that cAMP can regulate the total enzymatic activity of effector cells by two main mechanisms: 1-modify the activity of enzymes already synthesized by cells; 2-increase or decrease the rate of enzyme synthesis ${ }^{12}$. The role of cAMP in regulating the activity of protein kinases is especially large. Moreover, the simultaneous existence of several protein kinases activated by various cyclic nucleotides and catalyzing the formation of various proteins in one cell is assumed ${ }^{13-15}$. It is now well known that the action of a large number of hormones and biologically active substances is carried out with the participation of cAMP. The "primary" receptor for the action of hormones is adenylate cyclase, the activation of which in membranes leads to the accumulation of cAMP and the activation of protein kinase. The special role of cAMP plays in the processes of lipolysis, gene transcription, RNA and DNA synthesis. The variety of effects of cAMP makes it possible to consider it in the body as a universal regulator of biological processes ${ }^{16}$. The effect on the concentration of cAMP xenobiotics led to the idea that the enzymes involved in the synthesis and disintegration of cAMP are the point of application of the action of most xenobiotics. cAMP can exhibit regulatory functions at any metabolic level, in 
which various proteins are involved - nuclear regulatory proteins, enzymes, membrane proteins, receptors, hormones ${ }^{17}$.

Intracellular mediation plays an important role in the energy supply of cells of all types. The energy components of the adenylate cyclase system are adenosine monophosphate (AMP), adenosine diphosphate (ADP), adenosine triphosphate (ATP), inorganic phosphorus and $\mathrm{Mg}^{2+}$ ions. ATP, having a high energy potential, performs the function of a carrier of chemical energy. In various pathological processes, the metabolism of macroergic factors is disturbed, the ATP content in the cell decreases, so macroergic substances such as AMP, ADP, ATP, inorganic phosphate, are the "adenylate cyclase control“ system of the metabolic state of the cell $18-20$.

The formation of high-energy phosphate compounds is carried out in the reactions of oxidation of substrates in the Crebs cycle and associated oxidative phosphorylation. Changes in the dynamics of the activity of enzymes and nucleotides of the intracellular cyclic cascade in diseases of the kidneys, heart, liver, brain, alcohol intoxication were found. There is a significant decrease in the ATP content and the total amount of adenyl nucleotides with a simultaneous increase in AMP concentration, which is probably associated with inhibition of oxidative phosphorylation ${ }^{21-25}$.

The objective OF THE STUDY was to evaluate the intracellular cyclase cascade under the conditions of chronic fluoride intoxication in white rats of the Wistar population.

\section{Materials AND Methods}

This work is a fragment of KhMAPO study „Patho-chemical mechanisms of action of radioiodine on the organism and principles of their early diagnosis and correction", state registration number 0117U000589 of Ukrainian Scientific and Technical Information Center.

The research was conducted by the initiative creative group for scientific research from 2009 to 2014 at the Department of Biochemistry and vivarium of Kharkiv National Medical University MOH, Kharkiv, Ukraine.

The experimental part of the work was performed on 24 white rats of the Wistar population (12 experimental and 12 control). The control group was monitored for 2 weeks to assess their condition. After 2 weeks, healthy mature ( 3 months) males weighing 180-200 grams were selected, and the study program was conducted. In experimental rats, we administered intragastric, in the morning, on an empty stomach, a solution of sodium fluoride at a rate of $20 \mathrm{mg} / \mathrm{kg}$ of body weight. In this way, the development of fluoride intoxication was simulated. The duration of oral administration of the drug was 1.5 months. During this period, the development of fluoride intoxication was simulated in the animals. The state of intracellular metabolism was assessed by the adequacy of adenylate cyclase, guanylate cyclase, phosphodiesterase and the organs and tissues content of cyclic adenosine monophosphate (cAMP), cyclic guanosine monophosphate (cGMP) and the absorption of $\mathrm{Ca}^{2+}$ by the liver macrosomes and brain synaptosomes. To determine the activity of the cyclase cascade, generally accepted radioisotope techniques and the accompanying Ria Kit instructions (Slovakia, USA, UK) were used. The materials of the study were blood plasma, liver, brain, kidneys and spleen, isolated after decapitation of white rats.

\section{Results}

The study of the processes of intracellular mediation of the experimental and control groups of animals under conditions of chronic fluoride intoxication showed a change in almost all parts of the cyclase mediator system. Thus, in the experimental group of animals in plasma, there was an increase in the content of cAMP and a decrease in the level of cGMP, whereas in the liver, kidneys, and spleen there was a decrease in the concentration of cAMP and an increase in the number of cGMP (Table 1).

Analysis of the obtained results shows the presence of deep violations of intracellular metabolism in the conditions of the formation of fluoride intoxication. Prolonged intake of sodium fluoride resulted in a decrease in the level of adenylate cyclase in the brain and its increase in the liver (Table 2).

In the cerebral cortex of experimental animals, a decrease in adenylate cyclase activity and cAMP content was determined. At the same time, the activity of guanylate cyclase, phosphodiesterase, and cGMP content increased (Table 3).

The study of the effect of sodium fluoride revealed a significant impairment of the metabolism of $\mathrm{Ca}^{2+}$ ions in the experimental group of animals. The research results indicate a close relationship between the levels in the organs and tissues of cAMP, cGMP, adenylate cyclase, guanylate cyclase, phosphodiesterase, and calcium ions in biological substrates. Analysis of the absorption of ${ }^{45} \mathrm{Ca}^{2+}$ membranes by macroscopes of the liver and brain synaptosomes revealed a decrease in basal and $\mathrm{K}^{+}$- stimulated absorption of calcium ions by membrane preparations of nerve cells. In the liver, the $\mathrm{K}^{+}$-stimulated and basal absorption of $\mathrm{Ca}^{2+}$ ions was significantly less than in the brain. It should be noted that compared with the control, the studied values of the experimental group differed significantly (Table 4). 
Table 1. The content of cyclic nucleotides in the organs and tissues of white rats under fluoride intoxication conditions.

\begin{tabular}{|c|c|c|c|}
\hline \multirow{2}{*}{ Organs and tissues } & \multirow{2}{*}{ Indexes } & \multicolumn{2}{|c|}{ Groups of animals, $M \pm m$} \\
\hline & & Control $(n=12)$ & Experimental $(n=12)$ \\
\hline \multirow{2}{*}{ Blood plasma } & $\begin{array}{c}\mathrm{cAMP} \\
(\mathrm{nmol} / \mathrm{mL})\end{array}$ & $141.4 \pm 7.3$ & $\begin{array}{c}180.3 \pm 6.2 \\
p<0.05\end{array}$ \\
\hline & $\begin{array}{c}\mathrm{cGMP} \\
(\mathrm{nmol} / \mathrm{mL})\end{array}$ & $12.6 \pm 0.45$ & $\begin{array}{c}7.4 \pm 0.33 \\
p<0.05 \\
\end{array}$ \\
\hline \multirow{2}{*}{ Liver } & $\begin{array}{c}\mathrm{cAMP} \\
(\mathrm{nmol} / \mathrm{mL})\end{array}$ & $159.6 \pm 3.2$ & $\begin{array}{c}130.2 \pm 3.8 \\
p<0.05\end{array}$ \\
\hline & $\begin{array}{c}\mathrm{cGMP} \\
(\mathrm{nmol} / \mathrm{mL})\end{array}$ & $80.6 \pm 4.5$ & $\begin{array}{c}140.3 \pm 7.6 \\
\mathrm{p}<0.05\end{array}$ \\
\hline \multirow{2}{*}{ Kidney } & $\begin{array}{c}\mathrm{cAMP} \\
(\mathrm{nmol} / \mathrm{mL})\end{array}$ & $225.7 \pm 10.4$ & $\begin{array}{c}170.6 \pm 8.2 \\
p<0.05\end{array}$ \\
\hline & $\begin{array}{c}\mathrm{cGMP} \\
(\mathrm{nmol} / \mathrm{mL})\end{array}$ & $120.3 \pm 6.8$ & $\begin{array}{c}186.7 \pm 8.0 \\
\mathrm{p}<0.05\end{array}$ \\
\hline \multirow{2}{*}{ Spleen } & $\begin{array}{c}\mathrm{cAMP} \\
(\mathrm{nmol} / \mathrm{mL})\end{array}$ & $215.6 \pm 9.3$ & $\begin{array}{c}165.3 \pm 7.1 \\
\mathrm{p}<0.05\end{array}$ \\
\hline & $\begin{array}{c}\mathrm{cGMP} \\
(\mathrm{nmol} / \mathrm{mL})\end{array}$ & $115.7 \pm 5.9$ & $\begin{array}{c}170.4 \pm 6.6 \\
p<0.05\end{array}$ \\
\hline \multirow{2}{*}{ Cerebrum } & $\begin{array}{c}\mathrm{cAMP} \\
(\mathrm{nmol} / \mathrm{mL})\end{array}$ & $370.4 \pm 12.6$ & $\begin{array}{c}310.5 \pm 14.5 \\
\mathrm{p}<0.05\end{array}$ \\
\hline & $\begin{array}{c}\mathrm{cGMP} \\
(\mathrm{nmol} / \mathrm{mL})\end{array}$ & $260.3 \pm 7.8$ & $\begin{array}{c}340.2 \pm 9.3 \\
p<0.05\end{array}$ \\
\hline
\end{tabular}

Table 2. The effect of sodium fluoride on the activity of adenylate cyclase in preparations of liver microsomes membrane and brain synaptosome membrane ( $\mathrm{pmol} / \mathrm{cAMP} / \mathrm{mg}$ protein/min)

\begin{tabular}{|c|c|c|c|c|c|c|}
\hline \multirow{3}{*}{ Group of animals } & \multicolumn{6}{|c|}{ Organs, $\mathrm{M} \pm m$} \\
\hline & \multicolumn{3}{|c|}{ Cerebrum } & \multicolumn{3}{|c|}{ Cerebrum } \\
\hline & Adenylate cyclase & + isoproterinol & $+\mathrm{NaF}$ & Adenylate cyclase & + isoproterinol & $+\mathrm{NaF}$ \\
\hline Control ( $n=12)$ & $\begin{array}{l}1.29 \pm \\
0.03 \\
\end{array}$ & $\begin{array}{c}1.24 \pm \\
0.02 \\
\end{array}$ & $\begin{array}{c}1.58 \pm \\
0.04 \\
\end{array}$ & $\begin{array}{c}2.10 \pm \\
0.06 \\
\end{array}$ & $\begin{array}{c}2.90 \pm \\
0.04 \\
\end{array}$ & $\begin{array}{c}3.15 \pm \\
0.05 \\
\end{array}$ \\
\hline Experimental $(\mathrm{n}=12)$ & $\begin{array}{c}0.72 \pm \\
0.006 \\
p<0.05\end{array}$ & $\begin{array}{c}0.75 \pm \\
0.004 \\
p<0.05\end{array}$ & $\begin{array}{c}1.15 \pm \\
0.02 \\
p<0.05\end{array}$ & $\begin{array}{c}2.53 \pm \\
0.04 \\
p<0.05\end{array}$ & $\begin{array}{c}3.60 \pm \\
0.09 \\
p<0.05\end{array}$ & $\begin{array}{c}3.90 \pm \\
0.025 \\
p<0.05\end{array}$ \\
\hline
\end{tabular}

Table 3. The effect of sodium fluoride on the state of intracellular mediation of the cerebral cortex.

\begin{tabular}{|c|c|c|c|c|c|}
\hline \multirow[b]{2}{*}{ Group of animals } & \multicolumn{5}{|c|}{ Indexes, $M \pm m$} \\
\hline & $\begin{array}{c}\mathrm{AC} \\
\text { (pmol cAMP/mg } \\
\text { protein.min) }\end{array}$ & $\begin{array}{c}\text { cAMP }(f m o l ~ m g \\
\text { tissue })\end{array}$ & $\begin{array}{c}\mathrm{GC} \\
\text { (pmol cAMP/mg } \\
\text { protein.min) } \\
\end{array}$ & $\begin{array}{c}\text { cGMP } \\
\text { (fmol mg tissue) }\end{array}$ & $\begin{array}{c}\text { Phosphodiesterase } \\
\text { (nmol cAMP/mg } \\
\text { protein.min) }\end{array}$ \\
\hline Control $(n=12)$ & $97.4 \pm 3.2$ & $480.6 \pm 13.8$ & $0.82 \pm 0.06$ & $52.4 \pm 2.6$ & $4.80 \pm 0.33$ \\
\hline Experimental $(n=12)$ & $\begin{array}{c}58.5 \pm 4.2 \\
p<0.05\end{array}$ & $\begin{array}{c}260.1 \pm 12.5 \\
p<0.05\end{array}$ & $\begin{array}{c}1.76 \pm 0.04 \\
p<0.05\end{array}$ & $\begin{array}{c}84.3 \pm 5.7 \\
p<0.05\end{array}$ & $\begin{array}{c}8.16 \pm 0.59 \\
p<0.05\end{array}$ \\
\hline
\end{tabular}

\section{Discussion}

The important role in the processes of intracellular metabolism belongs to calcium ions ${ }^{26}$. Since the phosphorylation of functional proteins catalyzed by cyclic nucleotides has proven to be an effective regulator of a wide variety of cellular processes, the possibility of calcium participation in such regulation and ensuring metabolic homeostasis is of paramount importance in the pathogenesis of impaired functions ${ }^{27}$. The reversible effect of $\mathrm{Ca}^{2+}$ ions entering the cell through the surface membrane during cellular 
Table 4. The effect of sodium fluoride on absorption of $\mathrm{Ca}^{2+}$ by preparations of liver microsome membrane and brain synaptosomes of animals (imp/min $/ \mathrm{mg}$ protein).

\begin{tabular}{|c|c|c|c|c|}
\hline \multirow{3}{*}{ Group of animals } & \multicolumn{4}{|c|}{ Organs, $\mathrm{M} \pm \mathrm{m}$} \\
\hline & \multicolumn{2}{|c|}{ Cerebrum } & \multicolumn{2}{|c|}{ Liver } \\
\hline & Basal absorption & $\begin{array}{c}\mathrm{K}^{+}- \\
\text {stimulated absorption }\end{array}$ & Basal absorption & $\begin{array}{c}\mathrm{K}^{+}- \\
\text {stimulated absorption }\end{array}$ \\
\hline $\begin{array}{l}\text { Control } \\
(\mathrm{n}=12)\end{array}$ & $\begin{array}{l}16275.9 \pm \\
80.4\end{array}$ & $\begin{array}{c}25983.6 \pm \\
135.6\end{array}$ & $\begin{array}{c}12837.4 \pm \\
56.2 \\
\end{array}$ & $\begin{array}{c}13483.7 \pm \\
42.6\end{array}$ \\
\hline Experimental $(n=12)$ & $\begin{array}{c}10428.3 \pm \\
49.6 \\
p<0.05\end{array}$ & $\begin{array}{c}19844.3 \pm \\
90 a .3 \\
p<0.05\end{array}$ & $\begin{array}{c}9134.5 \pm \\
60.8 \\
p<0.05\end{array}$ & $\begin{array}{c}12356.4 \pm \\
58.2 \\
p<0.05\end{array}$ \\
\hline
\end{tabular}

activity is the most rapidly developing functional effect. $\mathrm{Ca}^{2+}$ ions entering the cell through calcium channels have a very specific effect on the surface membrane - they activate potassium ion channel ${ }^{28}$. The detected phenomenon was very common and was confirmed for many cells ${ }^{29}$. The inclusion of $\mathrm{Ca}^{2+}$-dependent potassium conductivity can also be one of the mechanisms of the cell's adaptation process to long-term external stress ${ }^{30,31}$.

Research results indicate that under fluoride intoxication conditions, there is a close relationship between the activity of adenylate cyclase, phosphodiesterase, guanylate cyclase and the content of cAMP, cGMP and calcium ions in organs and tissues. Thus, a decrease in the absorption of calcium ions may be associated with inhibition of adenylate cyclase and an increase in the activity of phosphodiesterase and a decrease in the level of cAMP. These processes, it should be assumed, were leading in the metabolism of $\mathrm{Ca}^{2+}$ ions and their incorporation into the membranes of the synaptosomes of nerve cells and the microsomes of the hepatocytes during fluoride intoxication.

\section{Conclusions}

The detected violations of intracellular mediation of the adenylate cyclase cascade (changes in the activity of adenylate cyclase, guanylate cyclase, phosphodiesterase, cAMP, cGMP content, and $\mathrm{Ca}^{2+}$ ion absorption by the nerve cell synaptosome membranes and hepatocyte microsomes) indicate a deep structural and metabolic restructuring and the possibility of multiple manifestations of pathological conditions in the formation of fluoride intoxication.

\section{Acknowledgements}

We thank all the members of the research team.

\section{Compliance with Ethics Requirements:}

„The authors declare no conflict of interest regarding this article"
"The authors declare that all the procedures and experiments of this study respect the ethical standards in the Helsinki Declaration of 1975, as revised in 2008(5), as well as the national law."

„All institutional and national guidelines for the care and use of laboratory animals were followed"

"No funding for this study"

\section{RefEREnCES}

1. Shashi A, Meenakshi G. Inhibitory effect of fluoride on $\mathrm{Na}^{+}, \mathrm{K}+$ ATPase activity in human erythrocyte membrane. Biol Trace Elem Res. 2015;168(2):340-348.

2. Hall ED, Vaishnav RA, Mustafa AG. Antioxidant therapies for traumatic brain injury. Neurotherapeutics. 2010;7(1):51-61.

3. Yadav N, Sharma S, Sharma K, et al. Protective role of diet supplements Spirulina and Tamarind fruit pulp on kidney in sodium fluoride exposed Swiss albino mice: histological and biochemical indices. Indian J Exp Biol. 2016;54(1):44-55.

4. Weydert CJ, Cullen JJ. Measurement of superoxide dismutase, catalase and glutathione peroxidase in cultured cells and tissue. Nat Protoc. 2010;5:51-66.

5. Falletti O, Cadet J, Favier A, Douki T. Trapping of 4-hydroxynonenal by glutathione efficiently prevents formation of DNA adducts in human cells. Free Radic Biol Med. 2007;42(8):1258-69.

6. Song GH, Gao JP, Wang CF, et al. Sodium fluoride induces apoptosis in the kidney of rats through caspase-mediated pathways and DNA damage. J Physiol Biochem. 2014; 70 (3):857-868.

7. Bonetti G, Carta M, Montagnana M, et al. Effectiveness of citrate buffer-fluoride mixture in Terumo tubes as an inhibitor of in vitro glycolysis. Biochem Med (Zagreb). 2016;26 (1):68-76

8. Choi AL, Sun G, Zhang Y, et al. Developmental fluoride neurotoxicity: a systematic review and meta-analysis. Environ Health Perspect. 2012;120(10):1362- 1368.

9. Chung YH, Shin CM, Joo KM, et al. Immunohistochemical study on the distribution of nitro-tyrosine and neuronal nitric oxide synthase in aged rat cerebellum. Brain Res. 2002; 951:316.

10. Zhang YL, Luo Q, Deng Q, et al. Genes associated with sodium fluoride-induced human osteoblast apoptosis. Int $J$ Clin Exp Med. 2015;8(8):13171-13178.

11. He LF, Chen JG. DNA damage, apoptosis and cell cycle changes induced by fluoride in rat oral mucosal cells and hepatocytes. World J Gastroenterol. 2006;12(7):1144-1148. 
12. Khan RA, Khan MR, Sahreen S. Brain antioxidant mark ers, cognitive performance and acetylcholinesterase activity of rats: efficiency of Sonchus asper. Behav Brain Funct. 2012;8:21

13. Bagmut I, Kolisnyk I, Titkova A. The pathochemical mechanisms of action of sodium flouride on the body. LAP Lambert Academic Publishing, 2017: 43 p.

14. Meng H, Zhang T, Liu W, et al. Sodium fluoride induces apoptosis through the downregulation of hypoxia-inducible factor- $1 \alpha$ in primary cultured rat chondrocytes. Int J Mol Med. 2014; 33(2):351-358.

15. Nguyen Ngoc TD, Son YO, Lim SS, et al. Sodium fluoride induces apoptosis in mouse embryonic stem cells through ROS-dependent and caspase- and JNK-mediated pathways. Toxicol Appl Pharmacol. 2012;259 (3):329-337.

16. Picco DC, Delbem AC, Sassaki KT, et al. The effect of chronic treatment with fluoride on salivary activity, tooth, and bone in spontaneously hypertensive rats (SHR). Naunyn Schmiedebergs Arch Pharmacol. 2014;387(4):321-328.

17. Bagmut I, Kolisnyk I, Titkova A, Petrenko T, Filipchenko S. Content of catecholamines in blood serum of rats under fluoride intoxication. Georgian Medical News. 2018;7-8(280-281):125-129.

18. Gottfredsen RH, Larsen UG, Enghild JJ, Petersen SV Hydrogen peroxide induce modifications of human extracellular superoxide dismutase that results in enzyme inhibition. Redox Biol. 2013;1:24-31.

19. Abdel-Gawad FA, Ashmawy MH, Zaki SM, et al. Lung damage after long-term exposure of adult rats to sodium fluoride. Arch Med Sci. 2014;10(5):1035- 1040.

20. Shetty KP, Satish SV, Gouda V, et al. Comparative evaluation and effect of organic and inorganic fluoride dentifrices on enamel microhardness: An in vitro study. J Int Soc Prev Community Dent. 2016;6(2):130-133.

21. Bains M, Hall ED. Antioxidant therapies in traumatic brain and spinal cord injury. Biochim Biophys Acta. 2012;1822(5):675-84.
22. Bagmut I, Kolisnyk I, Titkova A, Babiy L, Filipchenko S. The antioxidant system enzymes' activity in rats' brain, intoxicated with sodium fluoride in subtoxic doses. Arch Balk Med Union. 2018;53(4):506-511.

23. Cui H, Kong Y, Zhang H. Oxidative stress, mitochondrial dysfunction, and aging. J Signal Transduct. 2012;2012:646354.

24. Jothiramajayam M, Sinha S, Ghosh M, et al. Sodium fluoride promotes apoptosis by generation of reactive oxygen species in human lymphocytes. J Toxicol Environ Health A. 2014;77(21):1269-1280.

25. Tressaund A, Haufe G. Fluorine and Health. Elsevier, Hungary. 2008. 805 p.

26. Wei R, Luo G, Sun Z, et al. Chronic fluoride exposure-induced testicular toxicity is associated with inflammatory response in mice. Chemosphere. 2016;153:419-425.

27. Alhawij H, Lippert F, Martinez-Mier EA. Relative fluoride response of caries lesions created in fluorotic and sound teeth studied under remineralizing conditions. J Dent. 2015;43(1):103-109.

28. Yan X, Yang X, Hao X, et al. Sodium fluoride induces apoptosis in $\mathrm{H} 9 \mathrm{c} 2$ cardiomyocytes by altering mitochondrial membrane potential and intracellular ROS level. Biol Trace Elem Res. 2015;166(2):210-215.

29. Asaduzzaman Khan M, Tania M, Zhang DZ, Chen HC. Antioxidant enzymes and cancer. Chinese J Cancer Res. 2010;22:87-92

30. Fina BL, Lombarte M, Rigalli JP, et al. Fluoride increases superoxide production and impairs the respiratory chain in ROS 17/2.8 osteoblastic cells. PLoS One. 2014;9: Art. e100768.

31. Lee J, Han YE, Favorov O, et al. Fluoride induces a volume reduction in CA1 hippocampal slices via MAP kinase pathway through volume regulated anion channels. Exp Neurobiol. 2016;25(2):72-78. 